Ann. Biol. anim. Bioch. Biophys., 1979, 19 (5), 1521-1535.

\title{
In vitro studies of oocyte maturation and follicular metabolism in the pig
}

\author{
par Micheline GÉRARD, Y. MÉNÉZO *, P. ROMBAUTS, D. SZÖLLÖSI, \\ C. THIBAULT **
}

\author{
Station centrale de Physiologie animale, I. N. R. A., 78350 Jouy-en-Josas \\ * Laboratoire de Biologie, I. N. S. A., 69621 Villeurbanne, \\ ** Université P. et M. Curie, 4 Place Jussieu, 75005 Paris.
}

\begin{abstract}
Summary. In the in vivo developing follicles estrogen level raises proportionally to the size of the follicle. Progesterone concentration follows this curve parallelly at lower concentrations; a significant level of progesterone is, however, always noted. A switch of $\mathrm{E} 2 / \mathrm{Pg}$ ratio from 2.0 (or higher) to 0.15 occurs after the onset of estrus, when meiosis resumes. In vitro the E2/Pg ratio changes only in follicles of $7.0 \mathrm{~mm}$ or larger in diameter when either oFSH or oLH is added to the culture medium ; meiosis always resumes and the granulosa and cumulus cell reactions are similar to that occurring in vivo. During culture of follicles $<6 \mathrm{~mm}$ the reduction of the E2/Pg ratio is not observed whatever the nuclear status may be at the end of culture. For the nuclear maturation of oocytes high progesterone concentration thus does not seem to be necessary. No consistent morphological changes of the granulosa and cumulus cells could be associated with meiotic maturation of the oocyte. Glucose consumption increases when gonadotropins are added to the medium but maximal increase is only observed when meiosis resumes.
\end{abstract}

In mammals, gonadotropin surge is rapidly followed by cytological and biochemical changes in the follicle. Steroid secretion rises while there is a shift of the secretion from andro-estrogen to progesterone (Thibault, 1977). An increase of prostaglandin synthesis follows the rise of steroid. Important cytological changes are also evident such as cumulus cell dissociation, reorganization of granulosa layer and progressive disruption of the basement membrane. Steroid surge and prostaglandin increase are both involved in follicular rupture, not in oocyte meiotic resumption, at least when preovulatory steroid levels have been reached.

If loosening of cell to cell relationship is a prerequisite to follicular rupture and oocyte release, it has been suggested that the rupture of the contact between oocyte and granulosa cells through cumulus dissociation might explain meiotic resumption (Foote and Thibault, 1969 ; Anderson, 1977). However, meiotic resumption needs not

Reprints requests should be adressed to D. Szöllösi, Station centrale de Physiologie animale, I. N. R. A., 78350 Jouy-en-Josas, France. 
only the dissociation of cell junctions between oocyte and granulosa cells but the interruption of the synthesis of granulosa cell meiotic inhibiting factor (Tsafriri and Channing, 1975). Moreover in vitro studies have clearly shown that gonadotropins stimulate glycolysis (Hillensjö, 1976 ; Ménézo et al., 1978) and that the more suitable technique of culture of follicles involves a constant oxygen supply around the whole follicle (Ménézo et al., 1976) and it has been suggested that change in oxygen tension may be the trigger in oocyte meiotic resumption (Zeilmaker et al., 1972).

As the culture of the follicle has shown that complete oocyte maturation is obtained in the presence of gonadotropin as evidenced by the birth of young after in vitro maturation of intra follicular oocytes, we tried to find out if correlations exist between resumption of meiosis and the different biochemical and cytological events occurring in the presence of high levels of gonadotropins. We used the pig for these studies because an adequate number of synchronously developing follicles is available permitting experiments with different gonadotropins or in their absence on the same follicle population. Moreover the volume of the follicle is sufficiently large to compare individual evolution of both metabolism and oocyte maturation.

\section{Materials and methods.}

Normally cycling sows of the Large White and Landrace breeds were fed $100 \mathrm{mg}$ of Methallibure per day for 20 days starting at the mid luteal phase (Polge and Day, 1969). The day of withdrawal is designated as day 0 (D 0$)$. On $D 1$ the gilts are given an intramuscular injection of 1000 IU of PMSG. With this treatment the onset of estrus is generally detected on D 5, and ovulation occurs on D 6.5. This treatment is summarized in fig. 1.

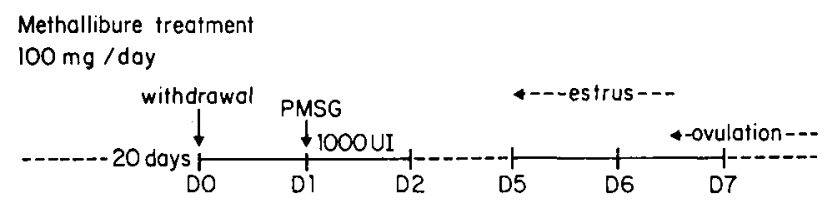

FIG. 1. - Schematic representation of Methallibure «synchronization 》 and subsequent treatment of gilts.

Ovaries were removed immediately after slaughter at the abattoir of the laboratory and placed into physiological saline solution in a thermos bottle at $37^{\circ} \mathrm{C}$. At the most five minutes passed between slaughter of the animal and the arrival of the ovaries in the culture room. The culture rooms are maintained between $27-30 \circ \mathrm{C}$. The ovaries were immediately cut into smaller pieces containing one to a few large follicles and placed into TC 199 medium, continually gassed with 57 p. $100 \mathrm{O}_{2}$, 5 p. $100 \mathrm{CO}_{2}$ and 38 p. $100 \mathrm{~N}_{2}$.

The largest follicles are isolated under a dissecting microscope with sterilized watchmakers forceps. Most of the theca externa is removed from the follicular wall. However, there is always a thin layer of theca externa which remains. After the follicles were cleaned they were placed in a continuous flow culture system (Ménézo 
ef al., 1976) for $48 \mathrm{hrs}$ under the same gas mixture indicated above. The time lapse between slaughter and culture never exceeded seventy minutes. The medium found most satisfactory is a fully defined medium B 2 (Ménézo, 1976). Five different conditions were used consistently to allow the comparison of the response of the same follicle population to various hormones. Control follicles were cultured without gonadotropins, while $1 \mu \mathrm{g} \mathrm{FSH,} 1 \mu \mathrm{g} \mathrm{LH}, 1 \mu \mathrm{g} \mathrm{FSH}$ and $1 \mu \mathrm{g} \mathrm{LH}$, or $0.5 \mu \mathrm{g} \mathrm{HCG}$ were used in experimental series. After 48 hrs of culture, the follicles are removed and transferred into $100 \mu \mathrm{l}$ of TC 199 medium and then opened in order to collect the entire content of follicular fluid which mixes with the TC 199. This mixture is aspirated into sterile $1 \mathrm{ml}$ tuberculine syringes and frozen until further analysis. The culture medium, usually $10-12 \mathrm{ml}$, is also frozen and then analysed.

To establish a control series of in vivo follicles, either normally cycling sows or methallibure-synchronized sows were slaughtered at increasing times after methallibure withdrawal or from day 17 to day 21 of the estrous cycle, before the expected lime of ovulation.

The estradiol $17 \beta$ and progesterone levels have been determined by radioimmunoassay. The antiserum to $17 \beta$ estradiol- 6 carboximethoxime-BSA and to $11 \alpha-$ hemisuccinate of progesterone-BSA were obtained from immunized rabbit in the laboratory (Dray et al., 1971). The respective antisera showed low levels of cross reaction with other estrogens and progestagens (16-epi-estriol 5 p. 100, 16-ceto estradiol $17 \beta 1.3$ p. 100 , estradiol $17 \alpha 0.88$ p. 100 , estrone 0.70 p. 100 , and estriol 0.52 p. 100 , desoxycorticosterone 7.5 p. 100 , pregna-4-ene $20 \beta$ ol-3-one 1.9 p. $100,17 \alpha$ hydroxyprogesterone 0.6 p. 100 , pregna-4-ene-20 $\alpha$-ol-3-one 0.26 p. 100).

All cultured follicles have been examined histologically to control atresia and the state of oocyte nuclear maturation. The opened follicles were fixed in BouinHolland solution in their entirety, embedded in paraplast, sectioned at 7-10 $\mu$ and stained with Regaud's hematoxylin and eosin.

For ultrastructural studies a small portion of the follicular wall carrying the cumulus, or the cumulus with the oocyte, has been individually fixed after its separation from the membrana granulosa. The fixative employed is $2.5 \mathrm{p} .100 \mathrm{glutaraldehyde}$ and 0.75 p. 100 paraformaldehyde in $0.075 \mathrm{M}$ cacodylate buffer at $\mathrm{pH} 7.2$ containing $5 \mu \mathrm{M} \mathrm{CaSO}_{1}$. To this mixture 0.5 p. 100 potassium ferri cyanid (Elbers et al., 1965) was added. After post osmication in a 2 p. 100 Osmium tetroxide solution in cacodylate buffer, the tissues were washed in $0.075 \mathrm{M}$ acetate buffer $\mathrm{pH} \mathrm{5.2,} \mathrm{and} \mathrm{stained} \mathrm{over-}$ night in a 0.5 p. 100 Uranyl acetate solution in the refrigerator at $4{ }^{\circ} \mathrm{C}$. The tissues were dehydrated in an ethanol series passed through propylene oxide and embedded in Epon 812. The thin sections are counterstained with aqueous 5 p. 100 Uranyl acelate solution and with lead citrate.

\section{Results.}

\section{Growth and development of the pig follicle in vivo}

A. Estradiol and progesterone contents. - At the end of methallibure treatment (D 0) estradiol and progesterone contents in follicular fluid are low. Secretion becomes noticeable between D 1 and D 2 ; at this moment the average follicular diameter 
is around $4 \mathrm{~mm}$. Steroid content increases parallelly with follicle growth and estradiol remains the dominant steroid up to $7 \mathrm{~mm}$. However, the relatively high content of progesterone must be noted (table 1).

TABLE 1

Follicular fluid of pigs

\begin{tabular}{|c|c|c|c|c|c|c|c|}
\hline \multirow{2}{*}{ Days } & \multirow{2}{*}{$\begin{array}{l}\text { Num- } \\
\text { ber of } \\
\text { follicles }\end{array}$} & \multirow{2}{*}{$\begin{array}{l}\text { Range of } \\
\text { follicle } \\
\text { diam. in } \mathrm{mm}\end{array}$} & \multirow{2}{*}{$\begin{array}{c}\text { Mean of } \\
\text { follicle } \\
\text { diam. in } \mathrm{mm}\end{array}$} & E2 & $\mathrm{Pg}$ & E2 & $\mathrm{Pg}$ \\
\hline & & & & & $/ \mathrm{ml}$ & \multicolumn{2}{|c|}{ ng/follicle } \\
\hline $\begin{array}{c}0 \\
1 \\
1,25 \\
2 \\
3-4 \\
3-5 \\
4-5 \\
6\end{array}$ & $\begin{array}{r}21 \\
8 \\
12 \\
11 \\
15 \\
36 \\
12 \\
7\end{array}$ & $\begin{array}{l}2.1-2.8 \\
2.5-3.1 \\
3.0-4.1 \\
4.0-5.2 \\
5.5-6.3 \\
6.0-7.2 \\
6.9-8.0 \\
7.2-8.4\end{array}$ & $\begin{array}{l}2.54 \pm 0.04 \\
2.86 \pm 0.12 \\
3.74 \pm 0.07 \\
4.67 \pm 0.12 \\
5.94 \pm 0.07 \\
6.76 \pm 0.06 \\
7.42 \pm 0.10 \\
7.97 \pm 0.15\end{array}$ & $\begin{aligned} &< 0.6 \\
&<1.0 \\
& 3.4 \pm 0.7 \\
& 22.9 \pm 3.9 \\
& 65.4 \pm 9.0 \\
& 94.0 \pm 6.4 \\
& 156.7 \pm 8.3 \\
& 31.1 \pm 0.9\end{aligned}$ & $\begin{array}{c}<0.75 \\
<0.75 \\
6.1 \pm 1.0 \\
9.2 \pm 1.5 \\
45.3 \pm 6.1 \\
85.0 \pm 8.2 \\
388.0 \pm 33.5 \\
204.7 \pm 13.2\end{array}$ & $\begin{array}{c}<0.05 \\
<0.07 \\
0.5 \pm 0.1 \\
3.9 \pm 0.7 \\
11.1 \pm 1.3 \\
20.8 \pm 1.8 \\
33.1 \pm 2.5 \\
8.51 \pm 0.3\end{array}$ & $\begin{array}{r}<0.09 \\
<0.09 \\
0.8 \pm 0.2 \\
1.5 \pm 0.3 \\
8.1 \pm 1.3 \\
18.2 \pm 1.5 \\
83.0 \pm 8.2 \\
56.4 \pm 4.5\end{array}$ \\
\hline
\end{tabular}

Values given are mean $\pm S E M . \quad E 2=$ estradiol $17 \beta . \quad \mathrm{Pg}=$ progesterone.

The maximum levels of both estradiol and progesterone are observed between $D 4$ and D 5 when follicular diameter reaches $7.5 \mathrm{~mm} ; \mathrm{E} \mathrm{2} / \mathrm{Pg}$ ratio is around 2 .

$18 \mathrm{hrs}$ after the onset of estrus and presumably after the discharge of LH-FSH, progesterone content rises rapidly and reaches twice the value of estrogen (table 1 ;

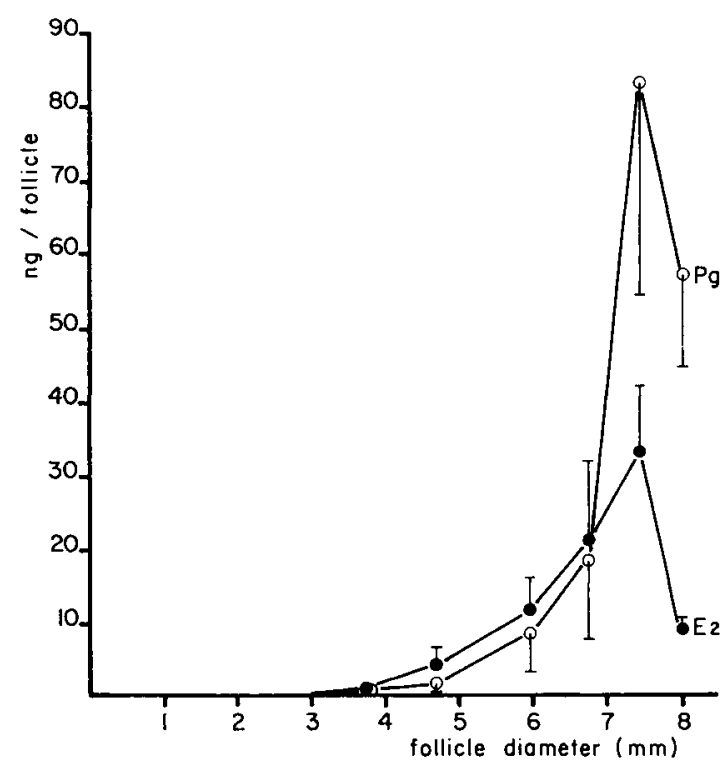

FIG. 2. - Estradiol $17 \beta$ and progesferone content of the follicular fluid of the Methallibure control series. 
fig. 2), and then estradiol and progesterone levels decrease although progesterone remains significantly higher than estradiol and $E 2 / \mathrm{Pg}$ ratio is 10 times lower, around 0.15 .

B. Cytological changes. - During the growth phase, the granulosa cell layer is a columnar, pseudostratified epithelium along a distinct basal lamina (fig. 3). The cells of this layer are closely associated, while the more internal layer towards the antrum becomes dispersed and polygonal in shape. The cumulus presents the same aspects (fig. 4).

In the oocyte, there is a peripherally located giant germinal vesicle with a distinct nucleolus. The chromatin is evenly dispersed until D2 (4 mm) (fig. 4). Following this, chromatin condenses along the nuclear envelope and, very distinctly, along the nucleolus (figs. 5, 6). Until D 2 the germinal vesicle (GV) is spherical and at a slight distance from the egg cell membrane while from D 3 onwards the GV flattens against it. At the same time the nuclear envelope becomes highly contorted.

The junctions between corona cell processes and oocyte membrane, which have been formed previously during oocyte growth, remain unchanged during the period studied (fig. 7).

\section{Meiotic resumption in infrafollicular oocyte during culture}

A. Role of gonadotropins (tables 2 and 3). - In the absence of gonadotropins in the medium, meiosis never resumes when the follicle is smaller than $6 \mathrm{~mm}$. For larger follicles meiosis has occasionally resumed during culture (3 cases/9).

In presence of HCG meiotic maturation is always achieved whatever the size of the follicle. The results with FSH and LH depend on the size of the follicle at the beginning of the culture. When follicles are smaller that $6 \mathrm{~mm}$, oLH seems less efficient than oFSH at least at the concentrations used. Metaphase II has not been observed with LH and 5 out of 11 oocytes remain in the dictyate stage. In contrast in presence of FSH or $\mathrm{FSH}+\mathrm{LH}, 20$ out of 25 oocytes have reached $\mathrm{M} 1$ or $\mathrm{M} 2$ (table 2 ).

TABLE 2

Effect of gonadotropins on oocyte nuclear maturation during 46-50 hrs of culture in follicles $<6 \mathrm{~mm}$

\begin{tabular}{|c|c|c|c|c|c|c|c|}
\hline $\begin{array}{l}\text { No } \\
\text { sows }\end{array}$ & $\begin{array}{l}\text { Average } \\
\text { diameter }\end{array}$ & Gonado. & GV & $\begin{array}{c}\text { Meiotic } \\
\text { resumption }\end{array}$ & Meta I & Meta II & $\begin{array}{c}\text { Meta } \\
+I+I I\end{array}$ \\
\hline $\begin{array}{l}5 \\
5 \\
5 \\
6 \\
7\end{array}$ & $\begin{array}{l}5.5 \\
6.0 \\
5.2 \\
5.1 \\
5.5\end{array}$ & $\begin{array}{l}\mathrm{HCG}^{0} \\
\text { FSH } \\
\text { LH } \\
\text { FSH }+ \text { LH }\end{array}$ & $\begin{array}{l}6 \\
0 \\
1 \\
5 \\
3\end{array}$ & $\begin{array}{l}1 \\
0 \\
1 \\
1 \\
0\end{array}$ & $\begin{array}{l}0 \\
0 \\
7 \\
5 \\
5\end{array}$ & $\begin{array}{l}0 \\
7 \\
4 \\
0 \\
4\end{array}$ & $\begin{array}{c}0 / 7 \\
7 / 7 \\
11 / 13 \\
5 / 11 \\
9 / 12\end{array}$ \\
\hline \multicolumn{7}{|c|}{ Total gonadotropins } & $32 / 43$ \\
\hline
\end{tabular}

$\mathrm{GV}=$ germinal vesicle. 


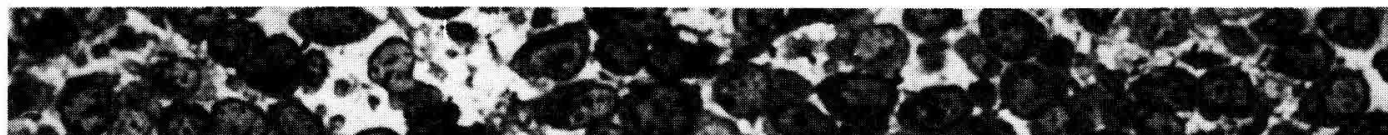

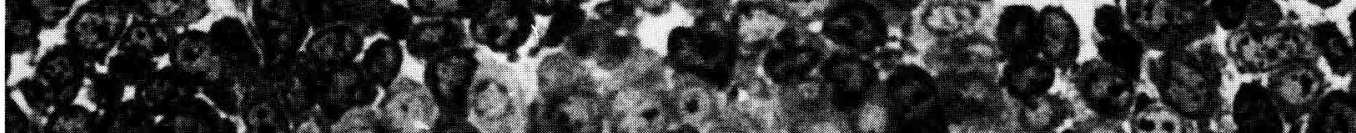

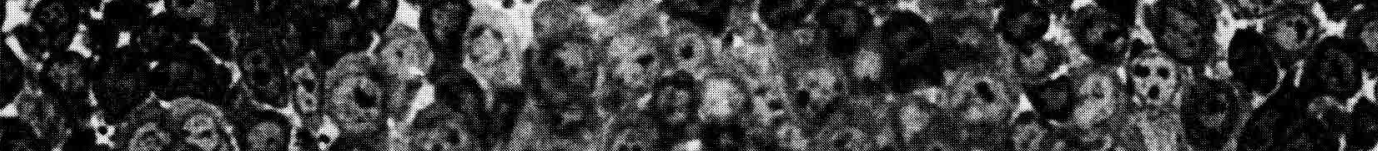
2.6.

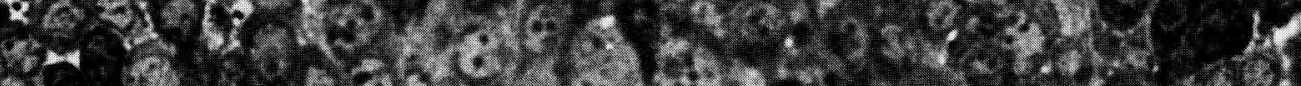

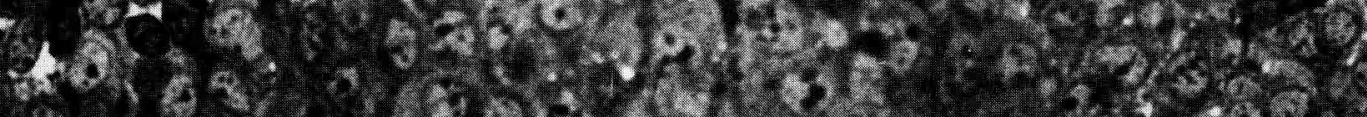

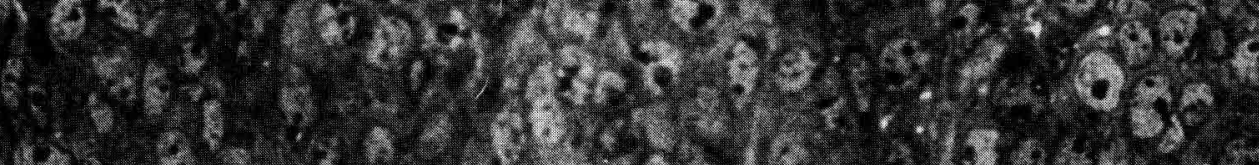

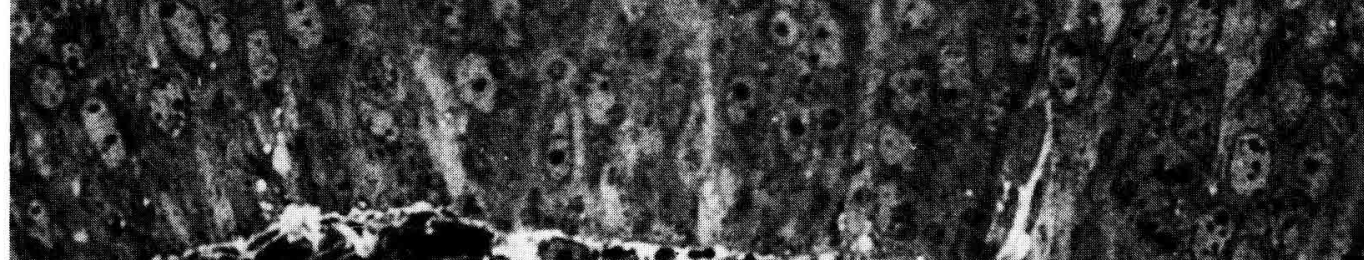

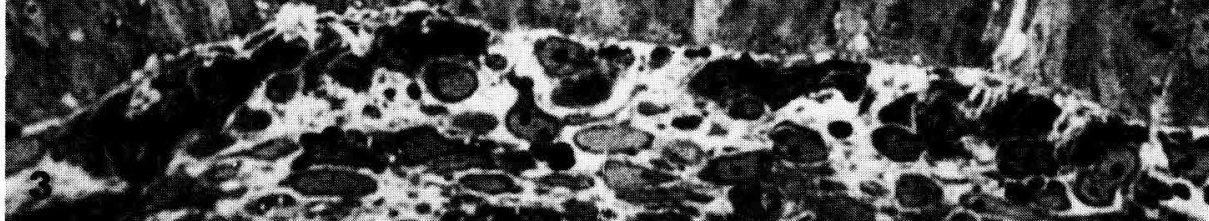

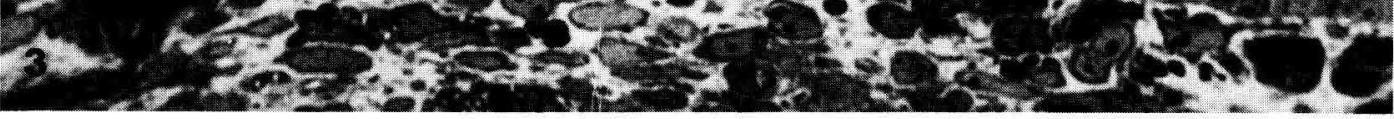
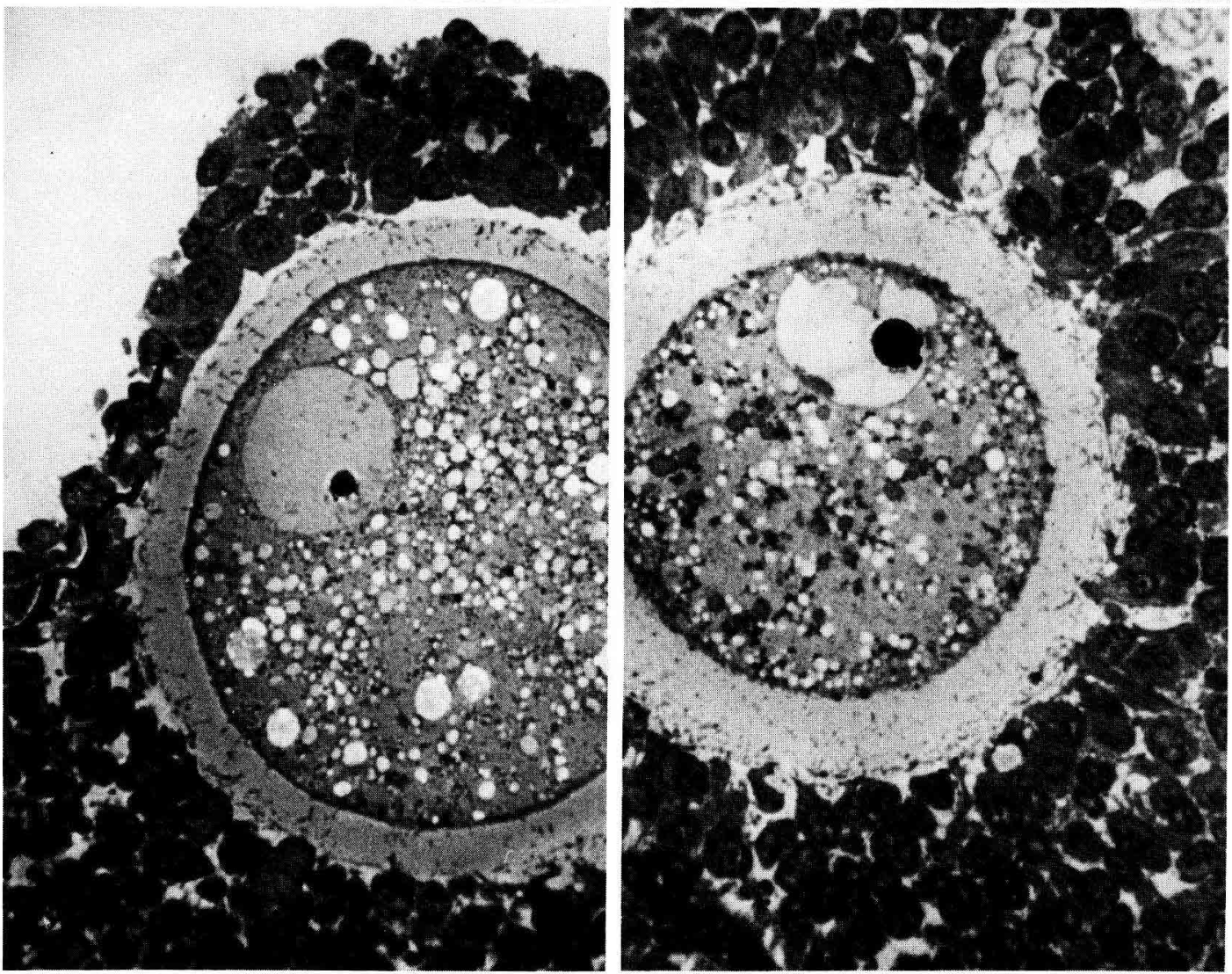
When follicles are larger than $6 \mathrm{~mm}$, with the addition of HCG, FSH or LH at the level of $1 \mu \mathrm{g} / \mathrm{ml}$, meiotic maturation is always completed (table 3 ).

TABLE 3

Effect of gonodotropins on oocyie nuclear maturation during $46-50 \mathrm{hrs}$ of culture in follicles $>6 \mathrm{~mm}$

\begin{tabular}{cccccccc}
\hline $\begin{array}{c}\text { No } \\
\text { sows }\end{array}$ & $\begin{array}{c}\text { Average } \\
\text { diameter }\end{array}$ & Gonado & GV & $\begin{array}{c}\text { Meiotic } \\
\text { resumption }\end{array}$ & Meta I & Meta II & $\begin{array}{c}\text { Meta } \\
\text { I+ II }\end{array}$ \\
\hline 5 & 6.72 & 0 & 6 & 1 & 1 & 1 & $2 / 9$ \\
\hline 2 & 6.9 & HCG & 0 & 0 & 1 & 5 & $6 / 6$ \\
1 & 6.75 & FSH & 0 & 0 & 0 & 2 & $2 / 2$ \\
2 & 7.0 & LH & 0 & 0 & 0 & 6 & $6 / 6$ \\
\hline \multicolumn{7}{c}{ Total gonadotropins } \\
\hline
\end{tabular}

B. Relation with steriod profiles (table 4). - Without the addition of gonadotropin to the culture medium, the production of estradiol remains high while the progesterone secretion is lower than in in vivo controls and the E2/Pg ratio is two to four times higher than in controls. With gonadotropin two situations can be distinguished according to the size of the follicle at the beginning of culture. When the follicles are isolated at $D 3$ (average diameter $5 \mathrm{~mm}$ ) gonadotropin enhanced steroid production, however, neither with LH, FSH nor with HCG is there a change in E2/Pg ratio as it occurs normally in vivo close to the $\mathrm{LH}$ surge. On the opposite, when follicles are recovered on D 5 (average diameter $>6 \mathrm{~mm}$ ), the E2/Pg ratio is low $(0.16)$ and very similar to the value observed in follicular fluid after the beginning of estrus.

These results show (table 4) that when E2/Pg ratio is low at the end of culture full meiotic maturation is always observed with any of the gonadotropins. This contrasts

\section{PLANCHE I}

FIG. 3. - A semi-thin section of follicular wall at D 3 from a Methallibure control series. Footh processes of granulosa cells from several levels abut on the follicular basement membrane. $\times 1200$.

FIG. 4. - The cumulus, containing the oocyte of a D 2 follicle. A spherical GV with nucleolus is peripherally located. The chromatin is uniformly dispersed and unperceptible with the staining employed. $\times 1200$.

FIG. 5. - Cumulus and oocyte of a D 3 follicle. The GV is flattened against the oocyte cell membrane. The envelope of the $G V$ is folded and chromatin condensations are seen along the NE and associated with the nucleolus. $\times 1200$. 


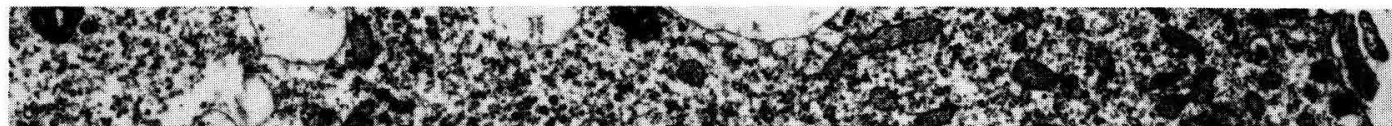

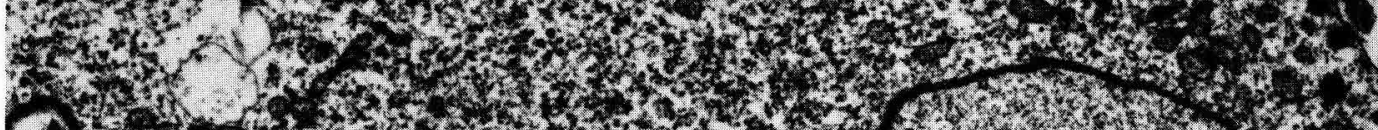

its

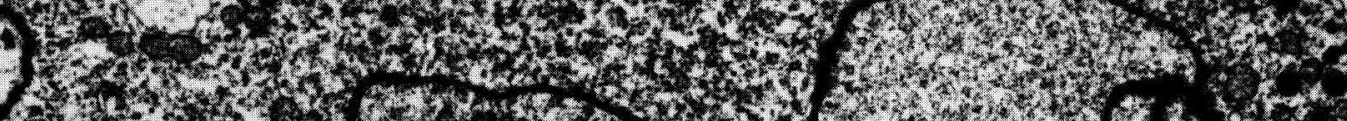

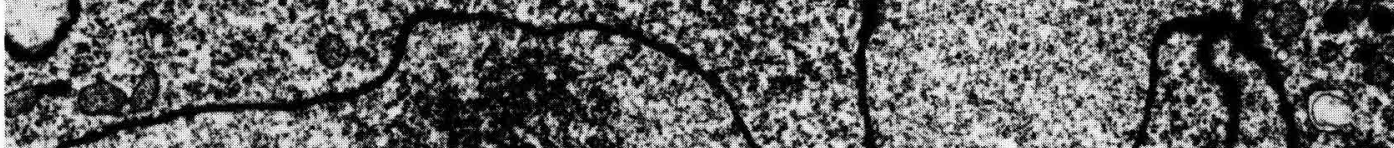

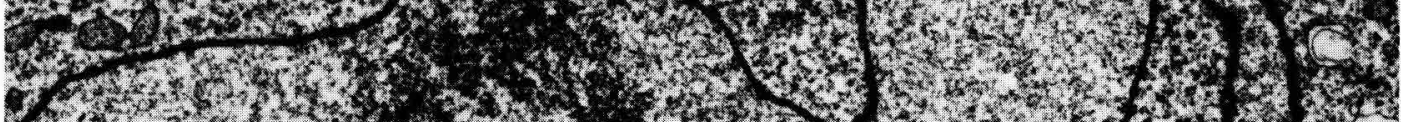

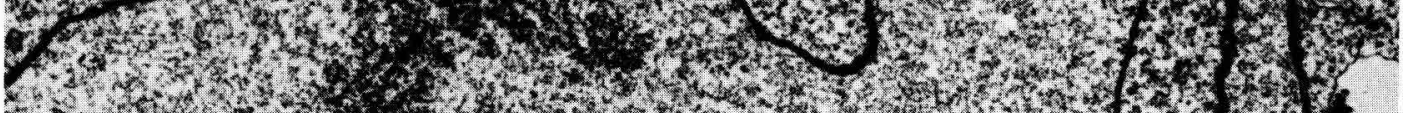

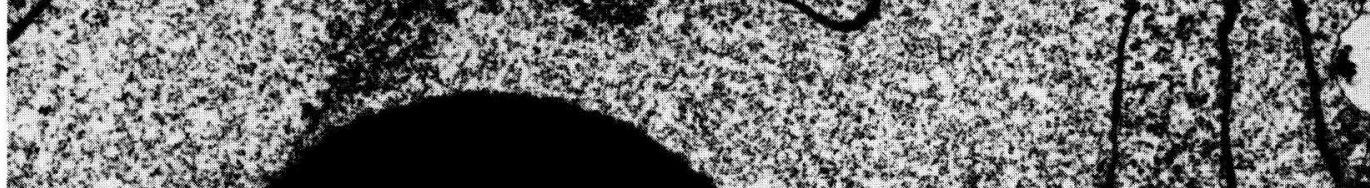

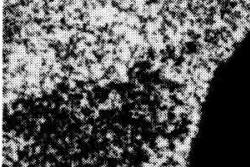

2. $x x^{2}$

(4) $18, x^{2}, 2$

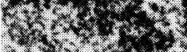

$8 x^{2}+x^{2}+3$

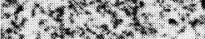

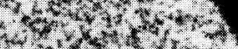

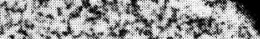

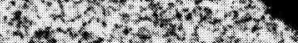

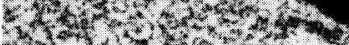

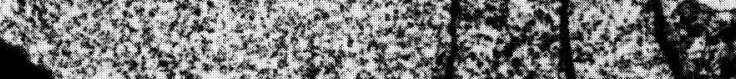

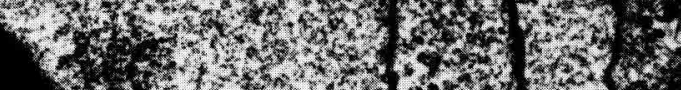

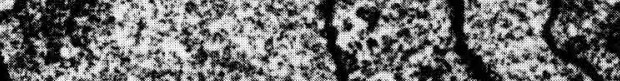

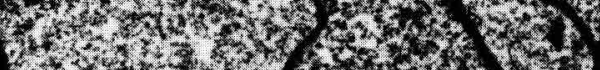

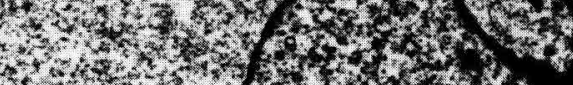

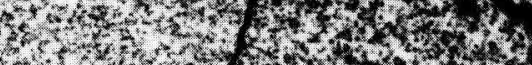

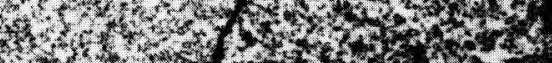

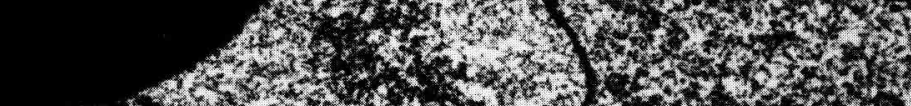

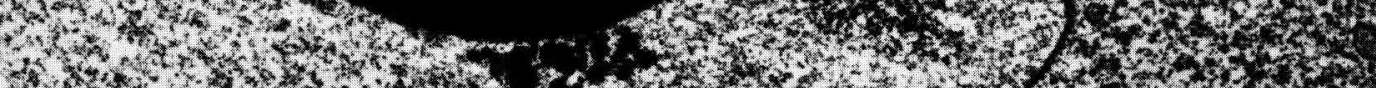

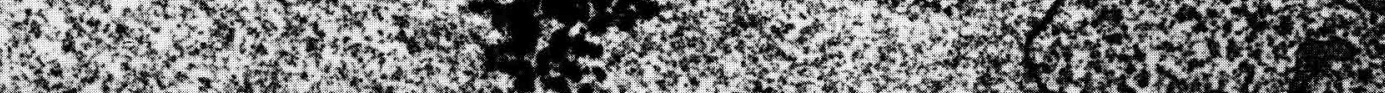

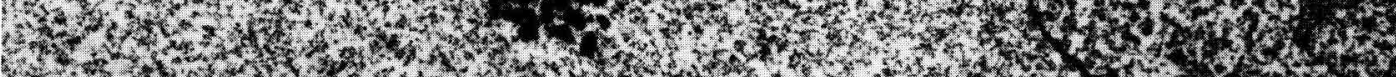

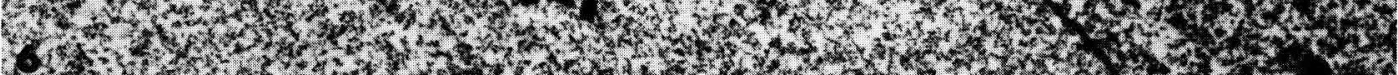

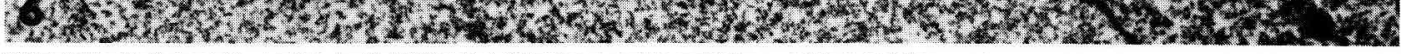

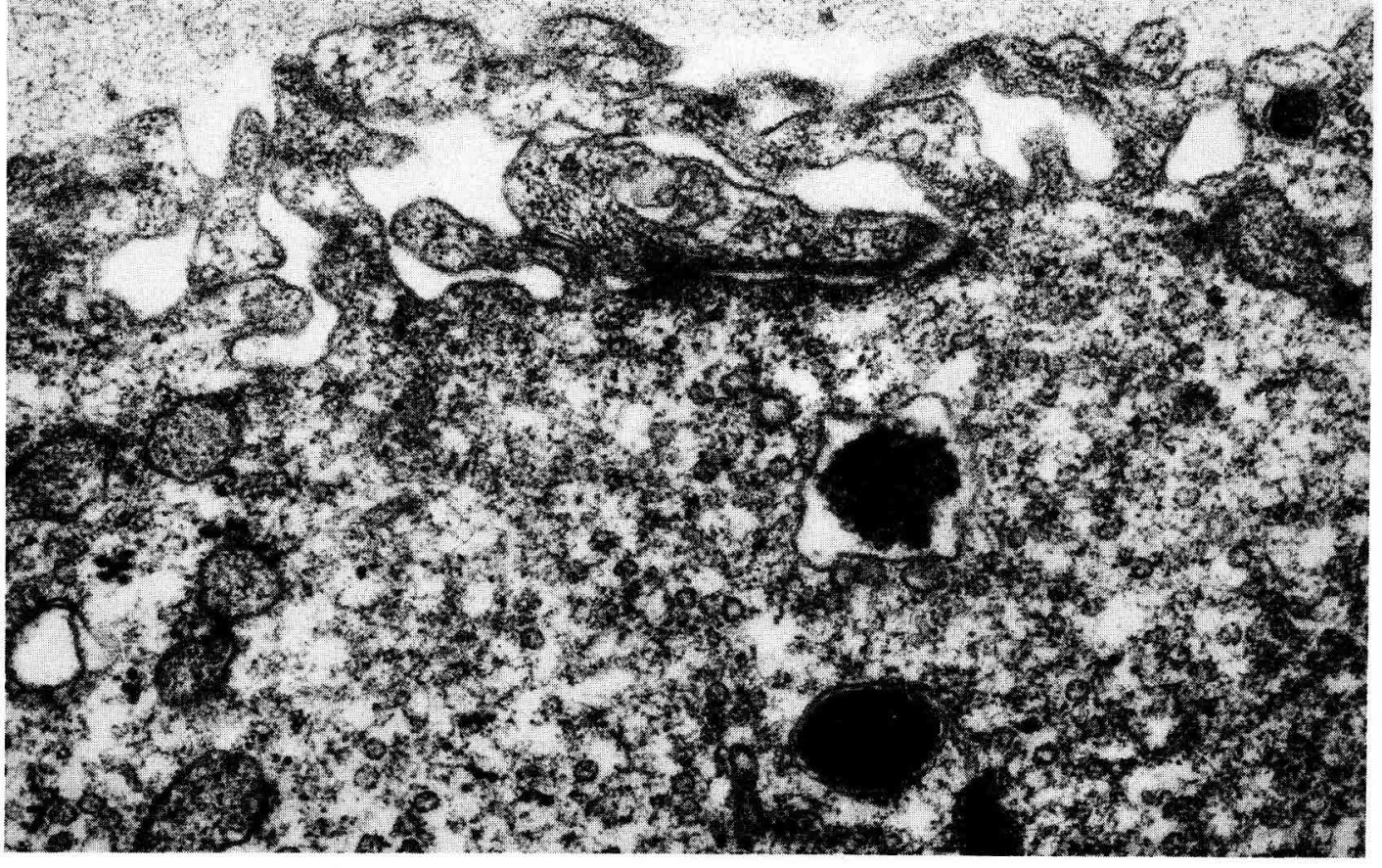


with follicles $<6 \mathrm{~mm}$ in which the E2/Pg ratio is greater than 1 and regular meiotic maturation is induced only with HCG.

\section{TABLE 4}

Action of gonadotropins on steroid secretions

\begin{tabular}{|c|c|c|c|c|c|c|}
\hline \multirow{2}{*}{$\begin{array}{l}\text { Follicle } \\
\text { diameter }\end{array}$} & \multirow{2}{*}{ Gonado. } & \multirow{2}{*}{$\begin{array}{c}\text { No } \\
\text { follicles }\end{array}$} & \multirow{2}{*}{$\begin{array}{l}\text { Follicle } \\
\text { diameter }\end{array}$} & \multicolumn{3}{|c|}{$\begin{array}{c}\text { Total steroid production in } \\
46-50 \mathrm{hrs}(\mathrm{ng})\end{array}$} \\
\hline & & & & $E 217 \beta$ & Progest. & $\mathrm{E} 2 / \mathrm{Pg}$ \\
\hline$<6 \mathrm{~mm}$ & $\begin{array}{l}\quad 0 \\
\text { HCG } \\
\text { FSH + LH } \\
\text { FSH } \\
\text { LH }\end{array}$ & $\begin{array}{l}4 \\
3 \\
7 \\
6 \\
4\end{array}$ & $\begin{array}{l}5.7 \pm 0.3 \\
5.9 \pm 0.2 \\
5.5 \pm 0.2 \\
5.1 \pm 0.2 \\
5.3 \pm 0.3\end{array}$ & $\begin{array}{c}116 \pm 13 \\
104 \pm 2 \\
104 \pm 9 \\
109 \pm 33 \\
84 \pm 9\end{array}$ & $\begin{array}{l}18 \pm 2 \\
51 \pm 3 \\
69 \pm 4 \\
62 \pm 6 \\
81 \pm 4\end{array}$ & $\begin{array}{l}6.6 \\
2.1 \\
1.5 \\
2.1 \\
1.1\end{array}$ \\
\hline \multirow{2}{*}{$>6 \mathrm{~mm}$} & $\begin{array}{c}0 \\
\text { LH/FSH }\end{array}$ & $\begin{array}{l}3 \\
9\end{array}$ & $\begin{array}{l}7.0+ \\
6.7 \pm 0.2\end{array}$ & $\begin{aligned} 87 & \\
59.6 & \pm 12\end{aligned}$ & $\begin{array}{r}34 \\
435\end{array}$ & $\begin{array}{l}2.5 \\
0.16\end{array}$ \\
\hline & $\begin{array}{l}\text { After LH } \\
\text { surge }\end{array}$ & 7 & $8.0 \pm 0.2$ & $8.5^{\ln t}$ & Intrafollicular content & ent \\
\hline
\end{tabular}

Values are mean $\pm \mathrm{SEM}$.

TABLE 5

Glucose consumption dependent on gonadotropin hormones

\begin{tabular}{lcc}
\hline $\begin{array}{l}\text { Gonadotropin } \\
\text { hormone }\end{array}$ & $\begin{array}{c}\text { No of } \\
\text { follicles }\end{array}$ & $\begin{array}{c}\text { Glucose consumption } \\
\mu \mathrm{g} / \mathrm{h}\end{array}$ \\
\hline 0 & 7 & $43.1 \pm 11.5$ \\
\hline FSH & 8 & $104.8 \pm 4.2$ \\
LH & 12 & $111.4 \pm 5.0$ \\
FSH + LH & 8 & $123.7 \pm 11.4$ \\
HCG & 11 & $118.1 \pm 9.1$ \\
\hline
\end{tabular}

Values given are mean $\pm \mathrm{SEM}$.

\section{PLANCHE \|}

FIG. 6. - A thin section parallel to that shown in fig. 5. The nuclear envelope is deeply folded. The large nucleolus is composed only of filamentous elements. Condensed chromatin is seen along the nucleolus and NE. $x, 7000$.

FIG. 7. - Two gap junctions are seen between one of the corona cell processes and the oocyte cell membrane. Two cortical granules, one in the condensation phase, are seen in the oocyte cortex. No cortical granules are found adjacent to the inner surface of the oocyte cell membrane. $\times 45000$. 


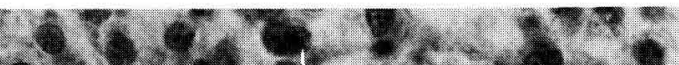
C.

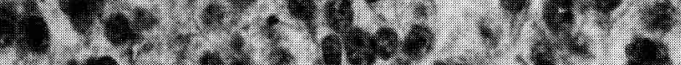

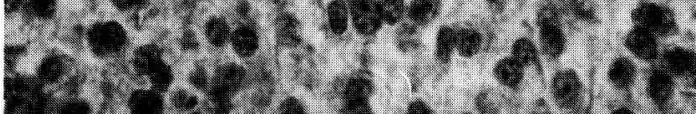

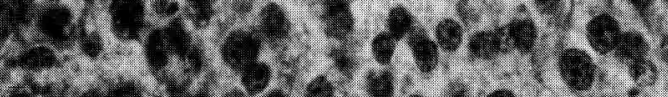

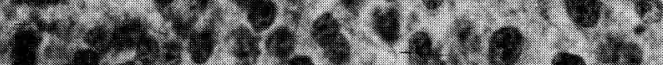

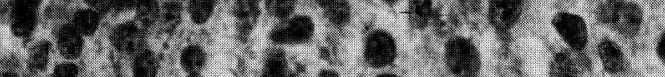

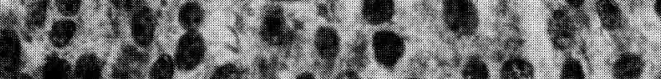

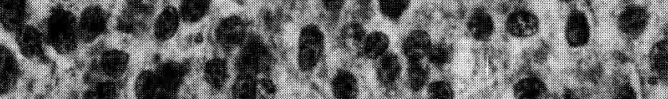

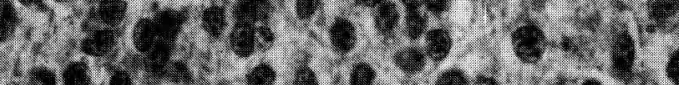
L

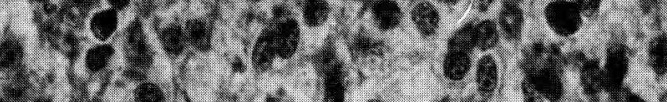

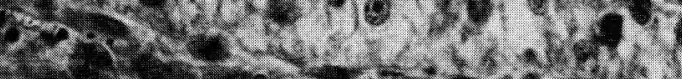

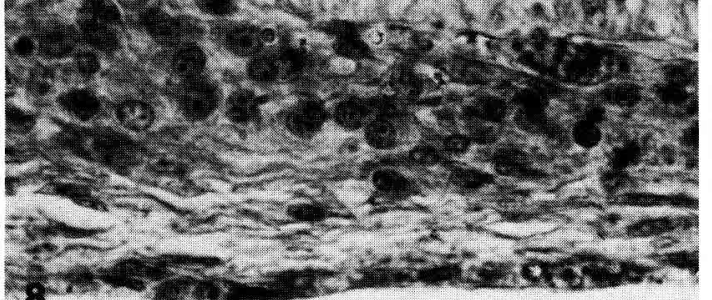

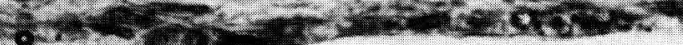

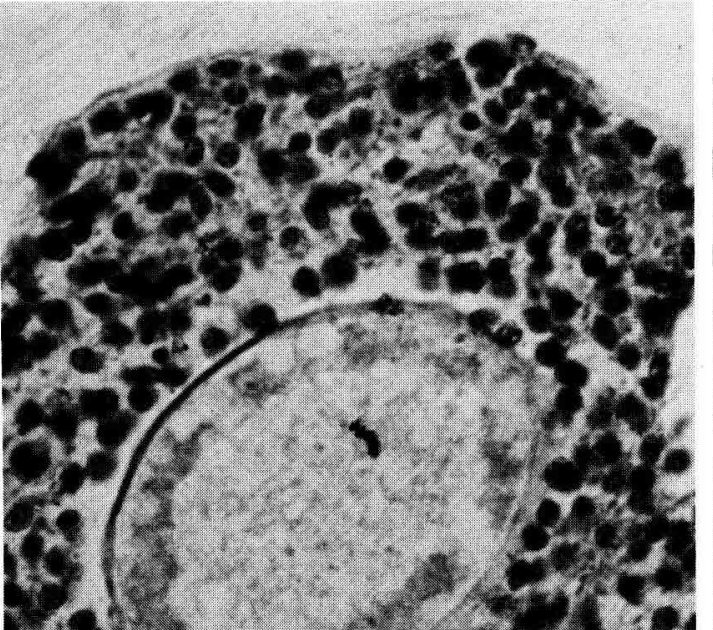

C.t.

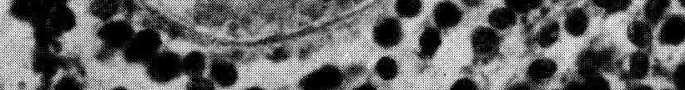

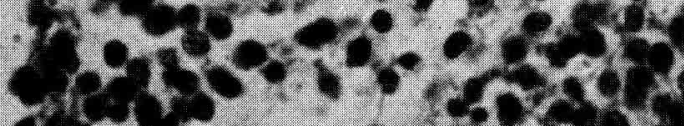

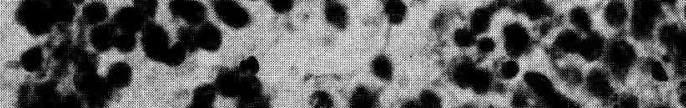

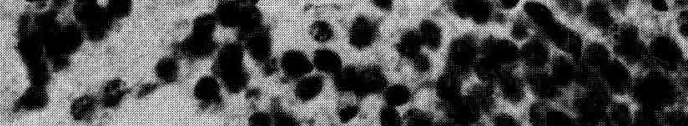

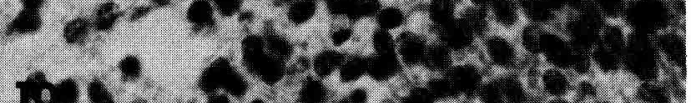

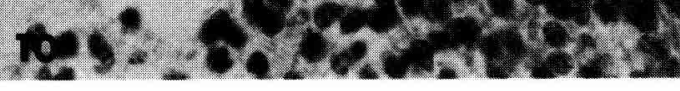

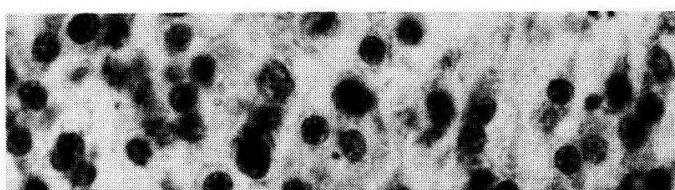
4 sezer 14

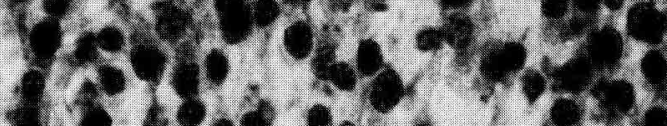
1.5: $\%$. 12 a by 05

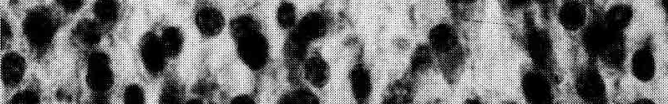

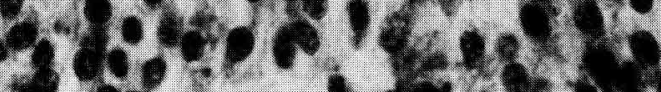
2. coris 23 .

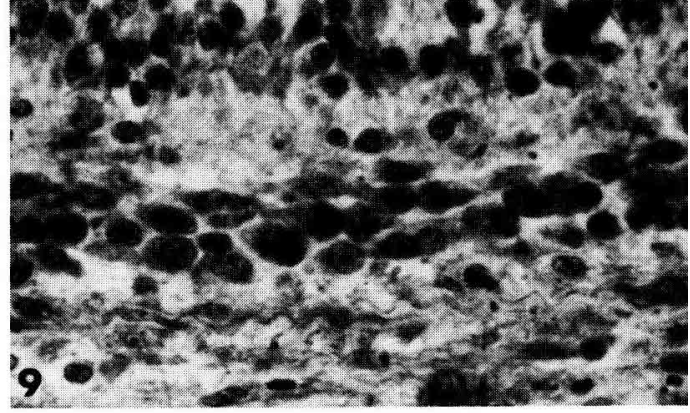
$4.6 .6 \% 0^{2}$ -5. $-2=0.45 \cdot 2$ $20.635=$ - 7 - 15

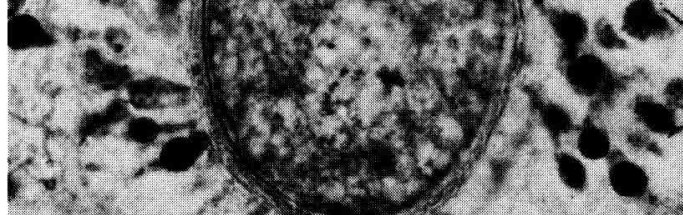
$\rightarrow 2010$ r.ohle a efor in

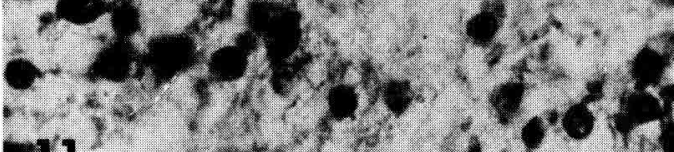

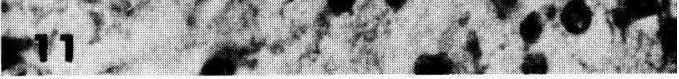


C. Relation with glycolysis. - From table 5 it is evident that any of the gonadotropins stimulate glycolysis during culture. However stimulation is highest when meiotic maturation occurs (table 6), and this increase is significant at the $P<0.005$ level.

TABLE 6

Relation between glucose consumption and state of the germinal vesicle of the oocyte

\begin{tabular}{cccccc}
\hline Sows & $\begin{array}{c}\text { No of } \\
\text { follicles }\end{array}$ & Dictyate & $\begin{array}{c}\text { No of } \\
\text { follicles }\end{array}$ & $\begin{array}{c}\text { Metaphase } \\
\text { I et II }\end{array}$ & $S$ \\
\hline $\begin{array}{l}\text { Normal cycling ...... } \\
\begin{array}{l}\text { Cycle following me- } \\
\text { thallibure treatment. }\end{array}\end{array}$ & 4 & $23.7 \pm 7.0$ & 11 & $110.3 \pm 7.8$ & $P<0.005$ \\
\hline
\end{tabular}

Values given are mean \pm SEM.

D. Relation with changes in granulosa layer and cumulus. - With FSH and LH the pseudo-stratified nature of granulosa layer is disturbed (fig. 8). However, the basement membrane remains visible. With HCG a greater dissociation of granulosa cells occurs and basement membrane disappears at the light optical level (fig. 9) (in this latter case the meiotic maturation is always completed).

Dissociation of cumulus cells always occurs with the three gonadotropins. Unexpectedly, there is no relation between cumulus dissociation and the state of oocyte nucleus. Nuclear maturation can occur without cumulus reaction in absence of gonadotropins (fig. 10) ; in contrast, complete dissociation of the cumulus by FSH or LH is not always followed by GVBD (fig. 11).

\section{PLANCHE III}

FIG. 8. - The granulosa cell layer is slightly disturbed when follicles are cultured with FSH. The follicular basement membrane is distinct. $\times 250$.

FIG. 9. - The dispersal of the granulosa cell layers is more extensive when HCG is added in the culture medium. The follicular basement membrone can be perceived but is no longer distinct. $\times 250$.

FIG. 10. - Metophase $l$ is found following spontaneous oocyfe maturation (without hormone). Corona cell and granulosa reactions did not occur. $\times 600$.

FIG. 11. - In presence of FSH, the cumulus cell reaction is distinct, while the GV may remain intact after 48 hrs of culture. $\ .600$. 


\section{Discussion.}

The normal in vivo developmental series of the pig follicle serves as a control for the subsequent in vifro developmental series of dissected pig follicles. Methallibure block and PMSG injection on day 1 serve as convenient «synchroniser 》 of small antral follicles to provide a population of uniform follicles; there is a slight variation in size per day, however. A consistent correlation between follicle size and steroid content was observed (Eiler and Nalbandov, 1977).

At D 0 and 1 (until a follicular diameter of $2.5 \mathrm{~mm}$ ) the estradiol and progesterone levels remain low and are barely measurable. During the following growth period until the follicle reaches $7 \mathrm{~mm}$ in diameter, estradiol predominates with a E2/Pg ratio between 1 and 2 while in larger follicles a steep increase in progesterone content reverses this trend and the E2/Pg ratio falls to 0.15 eighteen hours after the beginning of estrus. We have no data on LH surge, but it is known to occur soon after the onset of estrus (Henricks ef al., 1972). A similar inversion of E2/Pg ratio has been observed in sheep (Moor, 1979). At this moment, even though chromosomal condensation was initiated, the germinal vesicle remained intact containing a large nucleolus. GV breakdown follows 24-28 hrs after detection of estrus (Hunter and Polge, 1966).

In the experimental in vitro series, follicles were dissected either on day 3 or 5. The end point of successful culture is the resumption of meiosis and the reaction the granulosa and cumulus cells. This latter implies also the interruption of cell to cell contacts and communications between corona cells and the oocyte they surround, and a concomitant cytoplasmic cortical maturation of the oocyte. This sequence of cellular transformations renders the mammalian oocyte fertilizable (Gilula ef al., 1978 ; Szöllösi ef al., 1978).

When no gonadotropic hormones are added to the culture medium (control culture) none of the maturational events are observed if follicles smaller than $6 \mathrm{~mm}$ are cultured. Estradiol and progesterone secretion remains high but there is no shift from estradiol to progesterone as in the in vivo controls. There is no difference in steroidogenesis during culture whatever the nuclear state may be at the end of culture. oFSH and oLH individually are less efficient in inducing meiotic maturation than both together but FSH seems to be more potent than LH. The addition of either of the gonadotropic hormones induces 100 p. 100 oocyte maturation in follicles larger than $6 \mathrm{~mm}$ (10/10), while spontaneously only 3 out of 9 oocytes matured. A significantly higher rate of meiotic maturation was found in culture also by Tsafriri and Channing (1975) when oocyles were removed from follicles larger than $6 \mathrm{~mm}$ in diameter. The $\mathrm{E} 2 / \mathrm{Pg}$ ratio inversion is recorded in these follicles only following the addition of gonadotropins to the culture medium. Even with HCG, which stimulates meiotic maturation in all follicles studied (larger or smaller than $6 \mathrm{~mm}$ ), there is no increase in progesterone as in vivo after LH surge in follicles smaller than $6 \mathrm{~mm}$. It has been shown that high progesterone levels in the culture medium gave a higher rate of meiotic maturation in extrafollicular oocytes in the presence of estradiol $17 \beta$ (McGaughey, 1977). In contrast, when oocytes of mice and rabbits are cultured outside of the follicle, polar body production was reduced when both of these steroids were added to the culture medium, even though at an abnormally high level (Eppig and Koide, 1978 ; Moore-Smith et al., 1978). 
It is difficult to explain the full response to HCG and the relative irresponsiveness of oocytes from follicles smaller than $6 \mathrm{~mm}$ in term of absolute quantities of hormone, since the same quantity of LH becomes fully active in larger follicles.

An explanation based on the resistance of gonadotropins to be metabolized, however, fits well with the fact that the percentage of meiotic maturation is highest with HCG having a long half life and is smallest with the short lasting LH. This hypothesis can also explain why in human follicles LH is never detectable in small or medium sized follicles even if FSH is present in follicular fluid in all classes of antral follicles (McNatty ef al., 1979).

Thus far only a low rate of embryonic development was obtained of the in vitro matured oocytes after transfer to mated recipients (unpublished results). Even though with gonadotropins the most evident nuclear and cytoplasmic changes occur several of the less clearly visible events are probably either slowed down or reduced in extent or even absent all together.

The rate of glycolysis appears to be a consistant and reliable indicator of gonadotropin-follicular response and oocyte maturation. In follicles in which maturation events take place, glucose consumption is always more than double that of those which remain unresponsive. Significantly more lactate was produced when rat follicles were cultured for $4 \mathrm{hrs}$, after endogenous LH surge than when culture was initiated in the morning of proestrus. Lactate production was further enhanced in the former when $\mathrm{LH}$ was added to the incubation medium (Hillensjö, 1976². As in the case of the reportted studies, when high levels of lactate were produced (high levels of glucose consumption) GVBD always occurs.

Morphological criteria of the various cellular components cannot be employed reliably as a measure of follicular maturation. GV breakdown was observed in one case without any sign of response in granulosa or cumulus cell layers, while the reaction of the same does not always imply oocyte maturation. It remains true, however, that the granulosa cells are usually dispersed and the cumulus cell reaction has taken place in the hormonal milieu most favorable to induce meiotic maturation.

EEC Seminar on "Ovarian stimulation and egg quality in mammals », Luynes, France, octobre 1978.

Acknowledgements. - This work was supported in part by DGRST contract $n^{\circ} 75$ 7-1313 and EEC contract $n^{\circ} 300$. Mr Bertin's assistance for performing the radioimmunoassays is greatfully acknowledged. Purified gonadotropins were kindly provided by Dr. Jutisz and Mr. Poissonnier, CNRS Laboratories (Gif-sur-Yvelte).

Résumé. In vivo, dans les follicules en croissance, le niveau des œstrogènes augmente proportionnellement avec la taille du follicule. Le taux de progestérone suit la même évolution mais à des concentrations plus faibles. Une inversion du rapport E2/Pg de 2,0 ou plus à 0,15 apparaît seulement après le début de l'œstrus, associée à la reprise préovulatoire de la méiose.

In vitro, cette inversion ne se produit que dans les follicules de diamètre $\geqslant 7 \mathrm{~mm}$, en présence d'hormones FSH ou LH ovine ; dans ce cas, la reprise de la méiose a toujours lieu et les réactions de la granulosa et du cumulus sont comparables à celles observées in vivo. 
Dans les follicules de diamètre $<6 \mathrm{~mm}$, l'inversion du rapport E2/Pg n'est pas obtenue, même quand la maturation nucléaire se produit. Une concentration élevée de $\mathrm{Pg}$ ne semble donc pas indispensable à la reprise de la méiose. Aucun changement morphologique important, soit de la granulosa, soit du cumulus ne peut être associé avec la maturation nucléaire de l'ovocyte dans ces follicules.

La consommation de glucose augmente lorsque des hormones gonadotropes sont ajoutées au milieu de culture mais l'augmentation est la plus forte lorsque la reprise de la méiose a eu lieu.

\section{References}

ANDERSON E., 1977. Junctional complexes in the developing ovarian follicle and the preimplantation mammalian embryo with particular reference to gap junctions. Res. Reprod., 9, no 5.

DRAY F., TERQUI M., DESFOSSES M., CHAUFFOURNIER J. M., MOWSZOWICZ I., KAHN D., ROMBAUTS P., JAYLE M. F., 1971. Propriétés d'immunsérum anti 17ß-œestradiol oblenus chez différentes espèces animales avec l'antigène 17ß-cestradiol-6-0-carboxyméthoximeserum albumine de bceuf. C. R. Acad. Sci. Paris, sér. G, 273, 2380-2383.

EILER H., NALBANDOV A.V., 1977. Sex steroids in follicular fluid and blood plasma during the estrus cycle of pigs. Endocrinology, 100, 331-337.

ELBERS P. J., VERVERGAERT H. J., DEMEL R., 1965. Tricomplex fixation of phospholipids. J. Cell Biol., 23, 23-30.

EPPIG J. J., KOIDE S. L., 1978. Effects of progesterone and œstradiol $17 \beta$ on the spontaneous meiotic maturation of mouse oocytes. J. Reprod. Fert., 53, 99-101.

FOOTE W. D., THIBAULT C., 1969. Recherches expérimentales sur la maturation in vitro des ovocytes de truie et de veau. Ann. Biol. anim. Bioch. Biophys., 9, 329-349.

GILULA N. B., EPSTEIN M. L., BEERS W. H., 1978. Cell to cell communication and ovulation. A study of the cumulus-oocyte complex. J. Cell Biol., 78, 58-75.

HENRICKS D. M., GUTHRIE H. D., HANDLIN D. L., 1972. Plasma estrogen, progesterone and luteinizing hormone levels during estrus cycle in pigs. Biol. Reprod., 6, 210-218.

HILLENSJÖ T., 1976. Oocyte maturation and glycolysis in isolated preovulatory follicles of PMS injected immature rats. Acta endocr., 82, 801-830.

HUNTER R. H. F., POLGE C., 1966. Maturation of follicular oocytes in the pig after injection of human chorionic gonadotrophin. J. Reprod. Fert., 12, 525-531.

LINDNER H. J., TSAFRIRI A., LIEBERMAN M. E., ZOR U., KOCH Y., BAUMINGER S., BARNEA A., 1974. Gonadotropin action on cultured Graafian follicles : induction of maturation division of the mammalian oocyte and differentiation of the luteal cell. Rec. Progr. Hormone Res., 31, 79-127.

MCGAUGHEY R. W., 1977. The culture of pig oocytes in minimal medium, and the influence of progesterone and estradiol 17 $\beta$ on meiotic maturation. Endocrinology, 110, 39-45.

MCNATTY K. P., SAWERS R. S., 1975. Relationship between the endocrine environment within the Graafian follicle and the subsequent rate of progesterone secretion by human granulosa cells in vitro. J. Endocr., 66, 391-400.

MCNATTY K. P., MOORE-SMITH D., OSATHANDONDH R., RYAN K. J., 1979. The human antral follicle : functional correlates of growth and atresia. Ann. Biol. anim. Bioch. Biophys., 19, $1547-1558$.

MÉNÉZO Y., 1976. Milieu synthétique pour la survie et la maturation des gamètes et pour la culture de l'œuf fécondé. C. R. Acad. Sci. Paris, sér. D, 282, 1967-1970.

MÉNÉZO Y., GÉRARD M., THIBAULT C., 1976. Culture du follicule de de Graaf bovin dans un système à courant liquide et gazeux continu. C. R. Acad. Sci. Paris, sér. D, 283, 1309-1311.

MÉNÉZO Y., GÉRARD M., SZÖLLÖZI D., THIBAULT C., 1978. In vitro exchange between the follicle and its culture medium. Ann. Biol. anim. Bioch. Biophys., 18, 471-476.

MOOR R. M., 1977. Sites of steroid production in ovine Graafian follicles in culture. J. Endocr., 73, 123-130. 
MOORE-SMITH D., TYLER J. P., ERICKSON G. F., 1978. Effects of medium composition and progesterone on maturation in vitro of rabbit oocytes from Graafian follicles of different sizes. J. Reprod. Ferf., 54, 393-400.

POLGE C., DAY B. N., 1969. Induction of estrus and ovulation in swine during pituitary suppression with methallibure. J. Anim. Sci., 28, 73-75.

SZÖLLOSI D., GÉRARD M., MÉNÉZO Y., THIBAULT C., 1978. Permeability of ovarian follicle ; corona cell-oocyte relationship in mammals. Ann. Biol. anim. Bioch. Biophys., 18, 511-521.

THIBAULT C., GÉRARD M., MÉNÉZO Y., 1975. Acquisition par l'ovocyte de lapine et de veau du facteur de décondensation du noyau du spermatozoïde fécondant (MPGF). Ann. Biol. anim. Bioch. Biophys., 15, 705-714.

THIBAULT C., 1977. Are follicular maturation and oocyte maturation independant processes? J. Reprod. Fert., 51, 1-15.

TSAFRIRI A., CHANNING C. P., 1975. An inhibitory influence of granulosa cells and follicular fluid upon porcine oocyte meiosis in vitro. Endocrinology, 96, 922-927.

ZEILMAKER G. H., HULSMANN-WENSINCK F., VERHAMM C. M., 1972. Oxygen-triggered mouse oocyte maturation in vitro and lactate utilization by mouse oocytes and zygotes. J. Reprod. Fert., 29, 151-152. 